\title{
Analisis Location Quotient dalam Penentuan Sektor Basis dan Non Basis di Kabupaten Gorontalo
}

Kalzum R. Jumiyanti

\author{
Studi Pembangunan, Fakultas Ekonomi Universitas Gorontalo \\ email: yanti.kalzum@gmail.com
}

\begin{abstract}
Identifying basic sectors and sub-sectors is one of stages to plan strategic area expansion for the centre of economy growth. Therefore, Location Quotient Analysis is needed to understand how far the level of specialization of economy sectors in particular area in utilizing its basis sectors or leading sectors. Basic sectors can be determined by using Location Quotient (LQ) method. Variables used to calculate basis economy are from local GDP of an activity focused on activities in the local economy structures. Gross Domestic Product (GDP) is an important indicator to understand economy condition particularly in Gorontalo Regency in particular period, either based on current prices or constant price. Data collection process done by using secondary data survey based on documents from Statistics of Gorontalo Regency and Statistics of Gorontalo Province. From 2012 up to 2016, processing industry sectors and service sectors have been stable basis in terms of improving $L Q$ value and its GDP in an analysis period. This can be possible that those two sectors have contributed on the improvement of GDP of Gorontalo Regency including all other sectora that also become basis such as Mining and Excavation sector, agriculture sector and others.
\end{abstract}

Keywords: sektor basis, Location Quotient, PDRB, Kabupaten Gorontalo

\section{Pendahuluan}

Produk Domestik Regional Bruto (PDRB) merupakan salah satu perangkat data ekonomi yang dapat di gunakan untuk mengevaluasi kinerja pembangunan ekonomi suatu wilayah dalam suatu periode tertentu, baik atas dasar harga berlaku maupun atas dasar harga konstan. PDRB pada dasarnya merupakan jumlah nilai tambah yang dihasilkan oleh seluruh unit usaha dalam suatu wilayah tertentu, atau merupakan jumlah nilai barang dan jasa akhir yang dihasilkan oleh seluruh unit ekonomi pada suatu wilayah. Nilai PDRB dapat merepresentasikan pertumbuhan ekonomi suatu wilayah. Sebagai salah satu contoh pada pembahasan ini, dilakukan penghitungan dan analisis terhadap PDRB Kabupaten Gorontalo dari tahun 2012 hingga 2016 yang mengalami peningkatan pada setiap 
tahunnya. Peningkatan nilai PDRB Kabupaten Gorontalo mengindikasikan bahwa adanya peningkatan pada pertumbuhan ekonomi.

Pertumbuhan ekonomi menjadi bagian penting yang tidak terpisahkan dari tercapainya pembangunan ekonomi. Oleh sebab itu, diperlukan analisis terhadap kawasan yang menjadi andalan sektor unggulan untuk mendorong pertumbuhan ekonomi di Kabupaten Gorontalo. Sehingga perencanaan pembangunan ekonomi dapat direalisasikan secara terstruktur berdasarkan potensi sektoralnya. Jika ditinjau dari nilai sektor PDRB wilayah, sektor pertanian memiliki peran besar dalam peningkatan PDRB Kabupaten Gorontalo. Meskipun demikian, belum dapat dipastikan bahwa sektor pertanian merupakan basis dari Kabupaten Gorontalo, karena diperlukan perbandingan dengan wilayah yang lebih luas. Dalam hal ini, Provinsi Gorontalo menjadi pembanding nilai sektor PDRB Kabupaten Gorontalo. Penghitungan nilai Location Quotient (LQ) dibutuhkan untuk mengetahui sektor basis dan non-basis yang dimiliki oleh Kabupaten Gorontalo.

\section{KAJIAN TEORI}

\subsection{Location Quotient}

Analisis location quotient (LQ) merupakan suatu analisis yang digunakan untuk mengetahui sejauh mana tingkat spesialisasi sektor-sektor ekonomi di suatu wilayah yang memanfaatkan sektor basis atau leading sektor. Location quotient menghitung perbandingan share output sektor i di kota atau kabupaten dan share out sektor i di provinsi. Sektor unggulan disini berarti sektor bisnis yang tidak akan habis apabila dieksploitasi oleh pemerintah wilayah. Menurut Hood (1998 dalam Hendayana 2003), menyatakan bahwa location quotient adalah suatu alat pengembangan ekonomi yang lebih sederhana dengan segala kelebihan dan keterbatasannya.

Teknik LQ merupakan salah satu pendekatan yang umum digunakan dalam model ekonomi basis sebagai langkah awal untuk memahami sektor kegiatan yang menjadi pemicu pertumbuhan. LQ mengukur konsentrasi relatif atau derajat spesialisasi kegiatan ekonomi melalui pendekatan perbandingan. Teknik LQ banyak digunakan untuk membahas kondisi perekonomian, mengarah pada identifikasi spesialisasi kegiatan perekonomian atau mengukur konsentrasi relatif kegiatan ekonomi untuk mendapatkan gambaran dalam penetapan sektor unggulan sebagai leading sektor suatu kegiatan ekonomi industri. Dasar pembahasannya sering difokuskan pada aspek tenaga kerja dan pendapatan.

Teknik LQ belum bisa memberikan kesimpulan akhir dari sektor-sektor yang teridentifikasi sebagai sektor strategis. Namun untuk tahap pertama sudah cukup memberi gambaran akan kemampuan suatu wilayah dalam sektor yang teridentifikasi. Rumus matematika yang digunakan untuk membandingkan kemampuan sektor-sektor dari wilayah tersebut adalah (Daryanto dan Hafizrianda, 2010:21):

\section{Pendekatan Tenaga Kerja}

\section{Pendekatan Nilai Tambah / Pendapatan}

\section{Location Quotient Analysis}

\begin{tabular}{rl|}
$\mathrm{LQ}=\frac{\mathrm{Li} / \mathrm{Lt}}{\mathrm{Ni} / \mathrm{Nt}}$ \\
$\mathrm{LQ}=\frac{\mathrm{Vi} / \mathrm{Vt}}{\mathrm{Yi} / \mathrm{Yt}}$
\end{tabular}

Dimana :

$\mathrm{Li}=$ jumlah tenaga kerja sektor $\mathrm{i}$ pada tingkat wilayah yang lebih rendah

Lt $\quad=$ total tenaga kerja pada tingkat wilayah yang lebih rendah

$\mathrm{Ni}=$ jumlah tenaga kerjan sektor i pada tingkat wilayah yang lebih diatas

$\mathrm{Nt} \quad=$ total tenaga kerja pada tingkat wilayah yang lebih diatas

$\mathrm{Vi}=$ nilai PDRB sektor i pada tingkat wilayah yang lebih rendah

$\mathrm{Vt}=$ total PDRB pada tingkat wilayah yang lebih rendah 
$\mathrm{Yi} \quad=$ nilai $\mathrm{PDRB}$ sektor i pada tingkat wilayah yang lebih atas

Yt $\quad=$ Total PDRB pada tingkat wilayah yang lebih atas

Jika hasil perhitungan di formulasi di atas menghasilkan:

- LQ > 1 artinya, komoditas itu menjadi basis atau menjadi sumber pertumbuhan. Komoditas memiliki keunggulan komparatif, hasilnya tidak saja dapat memenuhi kebutuhan di wialyah bersangkutan akan tetapi juga dapat diekspor ke luar wilayah.

- $\mathrm{LQ}=1$ komoditas itu tergolong non-basis, tida memiliki keunggulan komparatif. Produksinya hanya cukup untuk memenuhi kebutuhan wilayah sendiri dan tidak mampu untuk diekspor.

- LQ $<1$ komoditas ini juga termasuk non-basis. Produksi komoditas di suatu wilayah tidak dapat memenuhi kebutuhan sendiri sehingga perlu pasokan atau impor dari luar.

Setiap metode analisis memiliki kelebihan dan keterbatasan, demikian halnya dengan metode LQ. Kelebihan metode LQ dalam mengidentifikasi komoditas unggulan antara lain:

1. LQ merupakan suatu alat analisis yang digunakan dengan mudah dan sederhana, serta cepat penggunaannya.

2. LQ dapat digunakan sebagai analisis awal untuk suatu wilayah, kemudian dapat dilanjutkan dengan alat analisis lainnya.

3. Perubahan tingkat spesialisasi dari setiap sektor dapat pula diketahui dengan membandingkan LQ dari tahun ke tahun.

4. Penerapannya tidak memerlukan program pengolahan data yang rumit. Penyelesaian analisis cukup dengan spread sheet dari Excel atau program Lotus jika datanya tidak terlalu banyak.

Dari segi keterbatasannya, metode LQ terbatas dalam:

1. Karena kesederhanaan pendekatan LQ ini, maka yang dituntut adalah akurasi data. Sebaik apapun hasil olahan LQ tidak akan banyak manfaatnya jika data yang digunakan tidak valid.

2. Pengumpulan data yang sangat valid sangat sulit dilakukan di lapangan sehingga mempersulit pengumpulan data.

3. Deliniasi wilayah kajian. Untuk menetapkan batasan wilayah yang dikaji dan ruang lingkup aktivitas, acuannya sering tidak jelas. Akibatnya hasil hitungan LQ terkadang aneh, tidak sama dengan apa yang kita duga.

4. Perlu diketahui bahwa nilai LQ dipengaruhi oleh berbagai faktor. Nilai hasil perhitungannya bias, karena tingkat disagregasi peubah spesialisasi, pemilihan peubah acuan, pemilihan entity yang diperbandingkan, pemilihan tahun dan kualitas data.

Komoditas yang menghasilkan nilai LQ $>1$ merupakan standar normatif untuk ditetapkan sebagai komoditas unggulan. Namun demikian ketika banyak komoditas di suatu wilayah yang menghasilkan LQ $>1$, sementara yang dicari hanya satu, maka yang harus dipilih adalah komoditas yang mendapatkan LQ paling tinggi. Karena nilai LQ yang semakin tinggi di suatu wilayah menunjukkan semakin tinggi pula potensi keunggulan komoditas tersebut. Dengan demikian, metode analisis LQ atau location quotient dapat digunakan secara mudah dan efisien jika ingin menghitung sektor unggulan suatu tempat. Kekurangankekurangan yang ditemui di lapangan dapat dikurangi dengan teliti dan rajin dalam mengumpulkan data. Hasil yang didapatkan kemudian adalah akurasi dan sektor unggulan yang dapat diberdayakan dan dikembangkan oleh seluruh masyarakat wilayah tertentu.

Berdasarkan data PDRB, kontribusi sektoral maupun laju pertumbuhan ekonomi di Kabupaten Gorontalo dan juga Provinsi Gorontalo, dapat dilakukan perhitungan menggunakan metode Location Quotient (LQ) untuk mencari keunggulan komparatif yang dimiliki Kabupaten Gorontalo terhadap Provinsi Gorontalo dengan 
cara mengidentifikasi sektor basis dan non basis. Data yang dipergunakan adalah data atas dasar harga konstan dengan tujuan untuk melihat perkembangan perekonomian secara riil yang pertumbuhannya tidak dipengaruhi oleh adanya perubahan harga atau inflasi/deflasi. Sektor-sektor yang termasuk dalam sektor basis menunjukkan bahwa sektor tersebut memiliki keunggulan komparatif. Dengan bertambah banyaknya kegiatan basis dalam suatu wilayah maka arus pendapatan yang masuk ke wilayah tersebut (monetary inflow) akan bertambah karena adanya kegiatan ekspor. Sebaliknya, kegiatan non basis menyebabkan keluarnya pendapatan dari wilayah tersebut ke wilayah lain (monetary outflow) yang disebabkan wilayah bersangkutan mengimpor kekurangan akan permintaan di sektor tersebut untuk memenuhi kebutuhan di dalam wilayah.

\subsection{Sektor Basis dan Non Basis}

Menurut Arsyad (1999:116) teori basis ekonomi menyatakan bahwa faktor penentu utama pertumbuhan ekonomi suatu daerah berhubungan langsung dengan permintaan akan barang dan jasa dari luar daerah. Teori basis ekonomi pada intinya membedakan aktivitas sektor basis dan aktivitas sektor non basis. Aktivitas sektor basis adalah pertumbuhan sektor tersebut menentukan pembangunan menyeluruh daerah itu, sedangkan aktivitas sektor non basis merupakan sektor skunder (city polowing) artinya tergantung perkembangan yang terjadi dari pembangunan yang menyeluruh.

Teori basis ekonomi berupaya untuk menemukan dan mengenali aktivitas basis dari suatu wilayah, kemudian meramalkan aktivitas itu dan menganalisis dampak tambahan dari aktivitas ekspor tersebut. Konsep kunci dari teori basis ekonomi adalah bahwa kegiatan ekspor merupakan mesin pertumbuhan. Tumbuh tidaknya suatu wilayah ditentukan oleh bagaimana kinerja wilayah itu terhadap permintaan akan barang dan jasa dari luar.

Lebih lanjut dalam analisis teori basis ekonomi, teori tersebut dapat digunakan untuk menentukan sektor dan subsektor potensial di Kabupaten Gorontalo berdasarkan Produk Domestik Regional Bruto (PDRB). Apabila sektor potensial tersebut dapat dikembangkan dengan baik tentunya mempunyai pengaruh yang signifikan terhadap pertumbuhan ekonomi suatu daerah, yang pada akhirnya dapat meningkatkan pendapatan daerah secara optimal. Menurut teori ini suatu daerah dapat dibedakan menjadi daerah andalan dan bukan andalan, yang selanjutnya dimodifikasi menjadi sektor/subsektor ekonomi potensial dan bukan sektor/subsektor ekonomi potensial.

\section{METODE PENELITIAN}

Proses pengumpulan data dilakukan dengan menggunakan survei berdasarkan data sekunder. Pengumpulan data sekunder bersumber dari dokumen yang dimiliki oleh Badan Pusat Statistik Kabupaten Gorontalo dan Badan Pusat Statistik Provinsi Gorontalo. Teknik analisa yang digunakan dalam penelitian ini yaitu untuk mengidentifikasi sektor dan sub sektor-sub sektor unggulan di Kabupaten Gorontalo dengan analisis LQ. Input data yang digunakan pada perhitungannya adalah nilai produksi tiap sektor dan sub sektor di Kabupaten Gorontalo dan Provinsi Gorontalo berdasarkan nilai pendapatan sektor dan sub sektor total.

\section{HASIL DAN PEMBAHASAN}

Untuk mengidentifikasi suatu sektor/subsektor ekonomi potensial dan bukan potensial digunakan alat analisis Location Quotient (LQ). Arsyad (1999:315) menjelaskan bahwa teknik Location Quotient dapat membagi kegiatan ekonomi suatu daerah menjadi dua golongan yaitu:

1. Kegiatan sektor ekonomi yang melayani pasar di daerah itu sendiri maupun di luar daerah yang bersangkutan. Sektor ekonomi seperti ini dinamakan sektor ekonomi potensial (basis) 
2. Kegiatan sektor ekonomi yang melayani pasar di daerah tersebut dinamakan sektor tidak potensial (non basis) atau local industry.

Teori ini menyatakan bahwa faktor penentu utama pertumbuhan ekonomi suatu daerah adalah berhubungan langsung dengan permintaan akan barang dan jasa dari luar daerah. Pertumbuhan industri-industri yang menggunakan sumberdaya lokal, termasuk tenaga kerja dan bahan baku untuk diekspor, akan menghasilkan kekayaan daerah dan penciptaan peluang kerja (job creation) (Arsyad, 1999).

Berikut adalah data - data PDRB ( Produk Domestik Regional Bruto) dari Kabupaten Gorontalo serta PDRB Provinsi Gorontalo sebagai bahan pembanding untuk analisis location quotient. Berikut adalah

Tabel : Produk Domestik Regional Bruto Atas Dasar Harga Konstan Menurut Lapangan Usaha di Kabupaten Gorontalo Tahun 2012 s/d Tahun 2016 (Juta Rupiah)

\begin{tabular}{|c|c|c|c|c|c|c|}
\hline \multirow{2}{*}{ No } & \multirow{2}{*}{ Lapangan Usaha } & \multicolumn{5}{|c|}{ Tahun } \\
\hline & & 2012 & 2013 & 2014 & 2015 & 2016 \\
\hline A & $\begin{array}{l}\text { Pertanian, } \\
\text { Kehutanan, dan } \\
\text { Perikanan }\end{array}$ & $2.200 .514,55$ & $2.380 .144,78$ & $2.566 .700,93$ & $2.666 .732,02$ & $2.819 .467,27$ \\
\hline B & $\begin{array}{l}\text { Pertambangan } \\
\text { dan Penggalian }\end{array}$ & $120.769,80$ & $127.261,59$ & $133.315,90$ & $141.209,58$ & $142.344,53$ \\
\hline $\mathrm{C}$ & $\begin{array}{l}\text { Industri } \\
\text { Pengolahan }\end{array}$ & $235.569,73$ & $259.474,78$ & $275.701,72$ & $288.273,40$ & $305.027,92$ \\
\hline $\mathrm{D}$ & $\begin{array}{l}\text { Pengadaan Listrik } \\
\text { dan Gas }\end{array}$ & $6.056,70$ & $6.463,44$ & $7.260,80$ & $7.348,44$ & $8.163,33$ \\
\hline $\mathrm{E}$ & $\begin{array}{l}\text { Pengadaan Air, } \\
\text { Pengelolaan } \\
\text { Sampah, Limbah } \\
\text { dan Daur ulang }\end{array}$ & $1.135,23$ & $1.238,15$ & $1.369,98$ & $1.405,72$ & $1.606,23$ \\
\hline $\mathrm{F}$ & Konstruksi & $871.666,02$ & $913.945,55$ & $986.133,04$ & $1.084 .547,68$ & $1.155 .225,72$ \\
\hline $\mathrm{G}$ & $\begin{array}{l}\text { Perdagangan } \\
\text { Besar dan } \\
\text { Eceran; Reparasi } \\
\text { Mobil dan Sepeda } \\
\text { Motor }\end{array}$ & $445.174,93$ & $484.953,94$ & $516.242,80$ & $545.699,63$ & $593.725,83$ \\
\hline H. & $\begin{array}{l}\text { Transportasi dan } \\
\text { Pergudangan }\end{array}$ & 436.020 .45 & $478.193,47$ & $518.829,35$ & $566.225,95$ & $616.512,23$ \\
\hline I & $\begin{array}{l}\text { Penyediaan } \\
\text { Akomodasi dan } \\
\text { Makan Minum }\end{array}$ & $107.043,99$ & $116.650,35$ & $123.205,65$ & $132.659,02$ & $142.761,00$ \\
\hline $\mathrm{J}$ & $\begin{array}{l}\text { Informasi dan } \\
\text { Komunikasi }\end{array}$ & $166.849,14$ & $180.313,72$ & $194.999,50$ & $214.157,73$ & $231.483,10$ \\
\hline $\mathrm{K}$ & $\begin{array}{l}\text { Jasa Keuangan } \\
\text { dan Asuransi }\end{array}$ & $223.669,63$ & $231.911,62$ & $242.398,28$ & $268.868,83$ & $319.793,01$ \\
\hline $\mathrm{L}$ & Real Estat & $57.427,44$ & $63.845,12$ & $68.785,22$ & $74.443,36$ & $80.426,82$ \\
\hline $\mathrm{M}$ & Jasa Perusahaan & $4.168,71$ & $4.419,14$ & $4.589,32$ & $4.846,07$ & $5.033,36$ \\
\hline $\mathrm{N}$ & $\begin{array}{l}\text { Administrasi } \\
\text { Pemerintahan, } \\
\text { Pertahanan dan } \\
\text { Jaminan Sosial } \\
\text { Wajib }\end{array}$ & $310.895,43$ & $328.754,76$ & $355.776,77$ & $369.066,56$ & $369.182,77$ \\
\hline $\mathrm{O}$ & Jasa Pendidikan & $172.424,72$ & $192.237,00$ & $218.335,03$ & $233.881,33$ & $245.636,71$ \\
\hline $\mathrm{P}$ & $\begin{array}{l}\text { Jasa Kesehatan } \\
\text { dan Kegiatan } \\
\text { Sosial }\end{array}$ & $149.802,72$ & $165.910,01$ & $184.727,72$ & $204.332,56$ & $220.747,73$ \\
\hline $\mathrm{Q}$ & Jasa Lainnya & $85.603,33$ & $91.415,01$ & $97.090,46$ & $101.855,69$ & $105.471,51$ \\
\hline & PDRB & $5.594 .792,60$ & $6.027 .132,43$ & $6.495 .462,11$ & $6.905 .553,63$ & $7.362 .609,08$ \\
\hline
\end{tabular}


Berikut adalah Tabel Produk Domestik Regional Bruto di Provinsi Gorontalo Tahun 2012 s/d Tahun 2016 (Milyar Rupiah)

\begin{tabular}{|c|c|c|c|c|c|c|}
\hline \multirow{2}{*}{ No } & \multirow{2}{*}{ Lapangan Usaha } & \multicolumn{5}{|c|}{ Tahun } \\
\hline & & 2012 & 2013 & 2014 & 2015 & 2016 \\
\hline A & $\begin{array}{l}\text { Pertanian, } \\
\text { Kehutanan, dan } \\
\text { Perikanan }\end{array}$ & $6.763,85$ & $11.791,87$ & $12.590,34$ & $13.382,97$ & $14,286,29$ \\
\hline B & $\begin{array}{l}\text { Pertambangan dan } \\
\text { Penggalian }\end{array}$ & 265,97 & 273,91 & 293,11 & 294,31 & 294,53 \\
\hline $\mathrm{C}$ & Industri Pengolahan & 737,13 & 796,02 & 843,80 & 883,13 & 941,23 \\
\hline $\mathrm{D}$ & $\begin{array}{l}\text { Pengadaan Listrik } \\
\text { dan Gas }\end{array}$ & 12,72 & 13,70 & 15,29 & 15,55 & 17,42 \\
\hline $\mathrm{E}$ & $\begin{array}{l}\text { Pengadaan Air, } \\
\text { Pengelolaan Sampah, } \\
\text { Limbah dan Daur } \\
\text { ulang }\end{array}$ & 8,94 & 9,54 & 10,25 & 10,50 & 12,06 \\
\hline $\mathrm{F}$ & Konstruksi & $2.136,49$ & $2.290,42$ & $2.470,12$ & $2.711,44$ & $2.849,32$ \\
\hline $\mathrm{G}$ & $\begin{array}{l}\text { Perdagangan Besar } \\
\text { dan Eceran; Reparasi } \\
\text { Mobil dan Sepeda } \\
\text { Motor }\end{array}$ & $1.806,27$ & $1.991,51$ & $2.151,87$ & $2.275,22$ & $2.500,71$ \\
\hline H. & $\begin{array}{l}\text { Transportasi dan } \\
\text { Pergudangan }\end{array}$ & $1.022,92$ & $1.112,50$ & $1.207,88$ & $1.324,74$ & $1.410,34$ \\
\hline I & $\begin{array}{l}\text { Penyediaan } \\
\text { Akomodasi dan } \\
\text { Makan Minum }\end{array}$ & 383,57 & 417,94 & 446,92 & 482,90 & 524,90 \\
\hline $\mathrm{J}$ & $\begin{array}{l}\text { Informasi dan } \\
\text { Komunikasi }\end{array}$ & 495,65 & 538,65 & 587,23 & 644,77 & 710,71 \\
\hline $\mathrm{K}$ & Jasa Keuangan & 675,94 & 675,93 & 710,31 & 742,57 & 817,90 \\
\hline $\mathrm{L}$ & Real Estat & 337,57 & 367,40 & 396,25 & 428,83 & 464,45 \\
\hline $\mathrm{M}$ & Jasa Perusahaan & 17,73 & 19,05 & 20,19 & 21,32 & 22,57 \\
\hline $\mathrm{N}$ & $\begin{array}{l}\text { Administrasi } \\
\text { Pemerintahan, } \\
\text { Pertahanan dan } \\
\text { Jaminan Sosial } \\
\text { Wajib }\end{array}$ & $1.685,04$ & $1.783,31$ & $1.906,73$ & $1.978,49$ & $1.976,63$ \\
\hline $\mathrm{O}$ & Jasa Pendidikan & 692,83 & 787,96 & 894,72 & 958,61 & 994,83 \\
\hline $\mathrm{P}$ & $\begin{array}{l}\text { Jasa Kesehatan dan } \\
\text { Kegiatan Sosial }\end{array}$ & 610,73 & 667,36 & 726,38 & 803,68 & 871,82 \\
\hline $\mathrm{Q}$ & Jasa Lainnya & 333,76 & 355,40 & 374,18 & 392,59 & 406,47 \\
\hline & PDRB & $17.987,07$ & $19.367,57$ & $20.775,80$ & $22.068,59$ & $23.507,15$ \\
\hline
\end{tabular}

Perhitungan LQ setiap sektor ekonomi di Kabupaten Gorontalo selama kurun waktu 5 tahun (2012-2016) adalah sebagai berikut :

1. Pertanian, Kehutanan, dan Perikanan

\begin{tabular}{|c|l|l|l|l|}
\hline \multicolumn{1}{|c|}{2012} & \multicolumn{1}{|c|}{2013} & \multicolumn{1}{c|}{2014} & \multicolumn{1}{c|}{2015} & 2016 \\
\hline $\begin{array}{l}\frac{2.200 .514,55 / 5.594 .792,60}{6.763 .850 / 17.987 .070} \\
=1,03\end{array}$ & $\begin{array}{l}2.380 .144,78 / 6.027 .132,43 \\
11.791 .870 / 19.367 .570 \\
=0,64\end{array}$ & $\begin{array}{l}\frac{2.566 .700,93 / 6.495 .462,11}{12.590 .340 / 20.775 .800} \\
=0,66\end{array}$ & $\begin{array}{l}2.666 .732,02 / 6.905 .553,63 \\
13.382 .970 / 22.068 .590 \\
=0,64\end{array}$ & $\begin{array}{l}\frac{2.819 .467,27 / 7.362 .609,08}{14.286 .290 / 23.507 .150} \\
=0,62\end{array}$ \\
\hline
\end{tabular}

Sektor Pertanian, Kehutanan, dan Perikanan, merupakan sektor basis karena hasil perhitungan LQ dalam periode 5 (lima) tahun menunjukkan nilai lebih dari 1 khususnya pada tahun 2012.

2. Pertambangan dan Penggalian

\begin{tabular}{|c|c|c|c|c|}
\hline 2012 & 2013 & 2014 & 2015 & 2016 \\
\hline $\begin{array}{l}\frac{120.769,80 / 5.594 .792,60}{265.970 / 17.987 .070} \\
=1,46\end{array}$ & $\begin{array}{l}\frac{127.261,59 / 6.027 .132,43}{273.910 / 19.367 .570} \\
=1,50\end{array}$ & $\begin{array}{l}\frac{133.315,90 / 6.495 .462,11}{293.110 / 20.775 .800} \\
=1,45\end{array}$ & $\begin{array}{l}\frac{141.209,58 / 6.905 .553,63}{294.310 / 22.068 .590} \\
=1,53\end{array}$ & $\begin{array}{l}\frac{142.344,53 / 7.362 .609,08}{294.530 / 23.507 .150} \\
=1,54\end{array}$ \\
\hline
\end{tabular}

Sektor Pertambangan Dan Penggalian, merupakan sektor basis karena hasil perhitungan LQ dalam periode 5 (lima) tahun menunjukkan hasil lebih dari 1 
3. Industri Pengolahan

\begin{tabular}{|c|c|c|c|c|}
\hline 2012 & 2013 & 2014 & 2015 & 2016 \\
\hline $\begin{array}{l}235.569,73 / 5.594 .792,60 \\
737.130 / 17.987 .070 \\
=1,03\end{array}$ & $\begin{array}{l}259.474,78 / 6.027 .132,43 \\
796.020 / 19.367 .570 \\
=1,05\end{array}$ & $\begin{array}{l}\frac{275.701,72 / 6.495 .462,11}{843.800 / 20.775 .800} \\
=1,04\end{array}$ & $\begin{array}{l}\frac{288.273,40 / 6.905 .553,63}{883.130 / 22.068 .590} \\
=1,04\end{array}$ & $\begin{array}{l}\frac{305.027,92 / 7.362 .609,08}{941.230 / 23.507 .150} \\
=1,03\end{array}$ \\
\hline
\end{tabular}

Sektor Industri Pengolahan, merupakan sektor basis karena hasil perhitungan LQ

selama periode 5 (lima) tahun terakhir menunjukkan hasil lebih dari 1.

4. Pengadaan Listrik dan Gas

\begin{tabular}{|c|l|l|l|l|}
\hline \multicolumn{1}{|c|}{2012} & \multicolumn{1}{|c|}{2013} & \multicolumn{1}{c|}{2014} & \multicolumn{1}{c|}{2015} & \multicolumn{1}{c|}{2016} \\
$\begin{array}{l}\frac{6.056,70 / 5.594 .792,60}{12.720 / 17.987 .070} \\
=1,57\end{array}$ & $\begin{array}{l}\frac{6.463,44 / 6.027 .132,43}{13.700 / 19.367 .570} \\
=1,57\end{array}$ & $\begin{array}{l}\frac{7.260,80 / 6.495 .462,11}{15.290 / 20.775 .800} \\
=1,57\end{array}$ & $\begin{array}{l}\frac{7.348,44 / 6.905 .553,63}{15.550 / 22.068 .590} \\
=1,57\end{array}$ & $\begin{array}{l}\frac{8.163,33 / 7.362 .609,08}{17.420 / 23.507 .150} \\
=1,57\end{array}$ \\
\hline
\end{tabular}

Sektor Pengadaan Listrik dan Gas, merupakan sektor basis karena hasil perhitungan LQ selama periode 5 (lima) tahun terakhir menunjukkan hasil lebih dari 1.

5. Pengadaan Air, Pengelolaan Sampah, Limbah dan Daur Ulang

\begin{tabular}{|c|c|c|c|c|}
\hline 2012 & 2013 & 2014 & 2015 & 2016 \\
\hline $\begin{array}{l}\frac{1.135,23 / 5.594 .792,60}{8.940 / 17.987 .070} \\
=0,40\end{array}$ & $\begin{array}{l}1.238,15 / 6.027 .132,43 \\
9.540 / 19.367 .570 \\
=0,40\end{array}$ & $\begin{array}{l}\frac{1.369,98 / 6.495 .462,11}{10.250 / 20.775 .800} \\
=0,40\end{array}$ & $\begin{array}{l}\frac{1.405,72 / 6.905 .553,63}{10.500 / 22.068 .590} \\
=0,40\end{array}$ & $\begin{array}{l}\frac{1.606,23 / 7.362 .609,08}{12.060 / 23.507 .150} \\
=0,40\end{array}$ \\
\hline
\end{tabular}

Sektor Pengadaan Air, Pengelolaan Sampah, Limbah dan Daur Ulang, merupakan

sektor non basis karena hasil perhitungan LQ dalam periode 5 (lima) tahun menunjukkan kurang dari 1.

6. Konstruksi

\begin{tabular}{|c|l|l|l|l|}
\hline \multicolumn{1}{|c|}{2012} & \multicolumn{1}{|c|}{2013} & \multicolumn{1}{c|}{2014} & \multicolumn{1}{c|}{2015} & \multicolumn{1}{c|}{2016} \\
\hline $\begin{array}{l}\frac{871.666,02 / 5.594 .792,60}{2.136 .490 / 17.987 .070} \\
=1,31\end{array}$ & $\begin{array}{l}\frac{913.945,55 / 6.027 .132,43}{2.290 .420 / 19.367 .570} \\
=1,28\end{array}$ & $\begin{array}{l}\frac{986.133,04 / 6.495 .462,11}{2.470 .120 / 20.775 .800} \\
=1,28\end{array}$ & $\begin{array}{l}\frac{1.084 .547,68 / 6.905 .553,63}{2.711 .440 / 22.068 .590} \\
=1,28\end{array}$ & $\begin{array}{l}\frac{1.155 .225,72 / 7.362 .609,08}{2.849 .320 / 23.507 .150} \\
=1,29\end{array}$ \\
\hline
\end{tabular}

Sektor Konstruksi, merupakan sektor basis karena hasil perhitungan LQ selama

periode 5 (lima) tahun terakhir menunjukkan hasil lebih dari 1.

7. Perdagangan Besar dan Eceran ; Reparasi Mobil dan Sepeda Motor

\begin{tabular}{|c|c|c|c|c|}
\hline 2012 & 2013 & 2014 & 2015 & 2016 \\
\hline $\begin{array}{l}445.174,93 / 5.594 .792,60 \\
1.806 .270 / 17.987 .070 \\
=0,79\end{array}$ & $\begin{array}{l}\frac{484.953,94 / 6.027 .132,43}{1.991 .510 / 19.367 .570} \\
=0,78\end{array}$ & $\begin{array}{l}516.242,80 / 6.495 .462,11 \\
2.151 .870 / 20.775 .800 \\
=0,77\end{array}$ & $\begin{array}{l}545.699,63 / 6.905 .553,63 \\
2.275 .220 / 22.068 .590 \\
=0,77\end{array}$ & $\begin{array}{l}\frac{593.725,83 / 7.362 .609,08}{2.500 .710 / 23.507 .150} \\
=0,75\end{array}$ \\
\hline
\end{tabular}

Sektor Perdagangan Besar dan Eceran, merupakan sektor non basis karena hasil

perhitungan LQ dalam periode 5 (lima) tahun menunjukkan kurang dari 1.

8. Transportasi dan Pergudangan

\begin{tabular}{|l|l|l|l|l|}
\hline \multicolumn{1}{|c|}{2012} & \multicolumn{1}{|c|}{2013} & \multicolumn{1}{c|}{2014} & \multicolumn{1}{c|}{2015} & 2016 \\
\hline $\begin{array}{l}\frac{436.020,45 / 5.594 .792,60}{1.022 .920 / 17.987 .070} \\
=1,37\end{array}$ & $\begin{array}{l}\frac{478.193,47 / 6.027 .132,43}{1.112 .500 / 19.367 .570} \\
=1,38\end{array}$ & $\begin{array}{l}\frac{518.829,35 / 6.495 .462,11}{1.207 .880 / 20.775 .800} \\
=1,38\end{array}$ & $\begin{array}{l}\frac{566.225,95 / 6.905 .553,63}{1.324 .740 / 22.068 .590} \\
=1,38\end{array}$ & $\begin{array}{l}\frac{616.512,23 / 7.362 .609,08}{1.410 .340 / 23.507 .150} \\
=1,40\end{array}$ \\
\hline
\end{tabular}

Sektor Transportasi dan Pergudangan, merupakan sektor basis karena hasil perhitungan LQ selama periode 5 (lima) tahun terakhir menunjukkan hasil lebih dari 1.

9. Penyediaan Akomodasi dan Makan Minum

\begin{tabular}{|c|c|c|c|c|}
\hline 2012 & 2013 & 2014 & 2015 & 2016 \\
\hline $\begin{array}{l}\frac{107.043,99 / 5.594 .792,60}{383.570 / 17.987 .070} \\
=0,89\end{array}$ & $\begin{array}{l}\frac{116.650,35 / 6.027 .132,43}{417.940 / 19.367 .570} \\
=0,89\end{array}$ & $\begin{array}{l}\frac{123.205,65 / 6.495 .462,11}{446.920 / 20.775 .800} \\
=0,88\end{array}$ & $\begin{array}{l}\frac{132.659,02 / 6.905 .553,63}{482.900 / 22.068 .590} \\
=0,88\end{array}$ & $\begin{array}{l}\frac{142.761,00 / 7.362 .609,08}{524.900 / 23.507 .150} \\
=0,84\end{array}$ \\
\hline
\end{tabular}

Sektor Penyediaan Akomodasi dan Makan Minum, merupakan sektor non basis

karena hasil perhitungan LQ dalam periode 5 (lima) tahun menunjukkan kurang dari 1.

10. Informasi dan Komunikasi

\begin{tabular}{|c|l|l|l|l|}
\hline 2012 & \multicolumn{1}{|c|}{2013} & \multicolumn{1}{c|}{2014} & \multicolumn{1}{c|}{2015} & \multicolumn{1}{c|}{2016} \\
\hline $\begin{array}{l}\frac{166.849,14 / 5.594 .792,60}{495.650 / 17.987 .070} \\
=1,08\end{array}$ & $\begin{array}{l}\frac{180.313,72 / 6.027 .132,43}{538.650 / 19.367 .570} \\
=1,07\end{array}$ & $\begin{array}{l}\frac{194.999,50 / 6.495 .462,11}{587.230 / 20.775 .800} \\
=1,06\end{array}$ & $\begin{array}{l}\frac{214.157,73 / 6.905 .553,63}{644.770 / 22.068 .590} \\
=1,06\end{array}$ & $\begin{array}{l}\frac{231.483,10 / 7.362 .609,08}{710.710 / 23.507 .150} \\
=1,04\end{array}$ \\
\hline
\end{tabular}


Sektor Informasi dan Komunikasi, merupakan sektor basis karena hasil perhitungan LQ selama periode 5 (lima) tahun terakhir menunjukkan hasil lebih dari 1.

11.Jasa Keuangan

\begin{tabular}{|c|c|c|c|c|}
\hline 2012 & 2013 & 2014 & 2015 & 2016 \\
\hline $\begin{array}{l}223.669,63 / 5.594 .792,60 \\
675.940 / 17.987 .070 \\
=1,06\end{array}$ & $\begin{array}{l}231.911,62 / 6.027 .132,43 \\
675.930 / 19.367 .570 \\
=1,10\end{array}$ & $\begin{array}{l}242.398,28 / 6.495 .462,11 \\
710.310 / 20.775 .800 \\
=1,09\end{array}$ & $\begin{array}{l}268.868,83 / 6.905 .553,63 \\
742.570 / 22.068 .590 \\
=1,16\end{array}$ & $\begin{array}{l}\frac{319.793,01 / 7.362 .609,08}{817.900 / 23.507 .150} \\
=1,25\end{array}$ \\
\hline
\end{tabular}

Sektor Jasa Keuangan, merupakan sektor basis karena hasil perhitungan LQ selama periode 5 (lima) tahun terakhir menunjukkan hasil lebih dari 1 .

12. Real Estat

\begin{tabular}{|c|c|c|c|c|}
\hline 2012 & 2013 & 2014 & 2015 & 2016 \\
\hline $\begin{array}{l}\frac{57.427,44 / 5.594 .792,60}{337.570 / 17.987 .070} \\
=0,54\end{array}$ & $\begin{array}{l}\frac{63.845,12 / 6.027 .132,43}{367.400 / 19.367 .570} \\
=0,56\end{array}$ & $\begin{array}{l}\frac{68.785,22 / 6.495 .462,11}{396.250 / 20.775 .800} \\
=0,56\end{array}$ & $\begin{array}{l}\frac{74.443,36 / 6.905 .553,63}{428.830 / 22.068 .590} \\
=0,56\end{array}$ & $\begin{array}{l}\frac{80.426,82 / 7.362 .609,08}{464.450 / 23.507 .150} \\
=0,55\end{array}$ \\
\hline
\end{tabular}

Sektor Pertambangan Dan Penggalian, merupakan sektor non basis karena hasil perhitungan LQ dalam periode 5 (lima) tahun menunjukkan kurang dari 1.

13. Jasa Perusahaan

\begin{tabular}{|c|c|c|c|c|}
\hline 2012 & 2013 & 2014 & 2015 & 2016 \\
\hline $\begin{array}{l}\frac{4.168,71 / 5.594 .792,60}{17.730 / 17.987 .070} \\
=0,7\end{array}$ & $\begin{array}{l}\frac{4.419,14 / 6.027 .132,43}{19.050 / 19.367 .570} \\
=0,7\end{array}$ & $\begin{array}{l}\frac{4.589,32 / 6.495 .462,11}{20.190 / 20.775 .800} \\
=0,7\end{array}$ & $\begin{array}{l}\frac{4.846,07 / 6.905 .553,63}{21.320 / 22.068 .590} \\
=0,7\end{array}$ & $\begin{array}{l}5.033,36 / 7.362 .609,08 \\
22.570 / 23.507 .150 \\
=0,7\end{array}$ \\
\hline
\end{tabular}

Sektor Jasa Perusahaan, merupakan sektor non basis karena hasil perhitungan

LQ dalam periode 5 (lima) tahun menunjukkan kurang dari 1.

14.Administrasi Pemerintahan, Pertahanan dan Jaminan Sosial Wajib

\begin{tabular}{|l|l|l|l|c|}
\hline \multicolumn{1}{|c|}{2012} & \multicolumn{1}{|c|}{2013} & \multicolumn{1}{c|}{2014} & 2015 & 2016 \\
\hline $\begin{array}{l}\frac{310.895,43 / 5.594 .792,60}{1.685 .040 / 17.987 .070} \\
=0,60\end{array}$ & $\begin{array}{l}\frac{328.754,76 / 6.027 .132,43}{1.783 .310 / 19.367 .570} \\
=0,60\end{array}$ & $\begin{array}{l}\frac{355.776,77 / 6.495 .462,11}{1.906 .730 / 20.775 .800} \\
=0,60\end{array}$ & $\begin{array}{l}\frac{369.066,56 / 6.905 .553,63}{1.978 .490 / 22.068 .590} \\
=0,60\end{array}$ & $\begin{array}{l}\frac{369.182,77 / 7.362 .609,08}{1.976 .630 / 23.507 .150} \\
=0,60\end{array}$ \\
\hline
\end{tabular}

Sektor Administrasi Pemerintahan, Pertahanan Dan Jaminan Sosial Wajib, merupakan sektor non basis karena hasil perhitungan LQ dalam periode 5 (lima) tahun menunjukkan kurang dari 1.

15. Jasa Pendidikan

\begin{tabular}{|c|c|c|c|c|}
\hline 2012 & 2013 & 2014 & 2015 & 2016 \\
\hline $\begin{array}{l}172.424,72 / 5.594 .792,60 \\
692.830 / 17.987 .070 \\
=0,80\end{array}$ & $\begin{array}{l}\frac{192.237,00 / 6.027 .132,43}{787.960 / 19.367 .570} \\
=0,78\end{array}$ & $\begin{array}{l}218.335,03 / 6.495 .462,11 \\
894.720 / 20.775 .800 \\
=0,78\end{array}$ & $\begin{array}{l}233.881,33 / 6.905 .553,63 \\
958.610 / 22.068 .590 \\
=0,78\end{array}$ & $\begin{array}{l}245.636,71 / 7.362 .609,08 \\
994.830 / 23.507 .150 \\
=0,79\end{array}$ \\
\hline
\end{tabular}

Sektor Jasa Pendidikan, merupakan sektor non basis karena hasil perhitungan

LQ dalam periode 5 (lima) tahun menunjukkan kurang dari 1.

16. Jasa Kesehatan dan Kegiatan Sosial

\begin{tabular}{|l|l|l|l|c|}
\hline \multicolumn{1}{|c|}{2012} & \multicolumn{1}{|c|}{2014} & \multicolumn{1}{c|}{2015} & 2016 \\
\hline $\begin{array}{l}\frac{149.802,72 / 5.594 .792,60}{610.730 / 17.987 .070} \\
=0,79\end{array}$ & $\begin{array}{l}\frac{165.910,01 / 6.027 .132,43}{667.360 / 19.367 .570} \\
=0,80\end{array}$ & $\begin{array}{l}\frac{184.727,72 / 6.495 .462,11}{726.380 / 20.775 .800} \\
=0,81\end{array}$ & $\begin{array}{l}\frac{204.332,56 / 6.905 .553,63}{803.680 / 22.068 .590} \\
=0,81\end{array}$ & $\begin{array}{l}\frac{220.747,73 / 7.362 .609,08}{871.820 / 23.507 .150} \\
=0,81\end{array}$ \\
\hline
\end{tabular}

Sektor Jasa Kesehatan dan Kegiatan Sosial, merupakan sektor non basis karena

hasil perhitungan LQ dalam periode 5 (lima) tahun menunjukkan kurang dari 1.

17. Jasa Lainnya

\begin{tabular}{|c|c|c|c|c|}
\hline 2012 & 2013 & 2014 & 2015 & 2016 \\
\hline $\begin{array}{l}\frac{85.603,33 / 5.594 .792,60}{333.760 / 17.987 .070} \\
=0,83\end{array}$ & $\begin{array}{l}\frac{91.415,01 / 6.027 .132,43}{355.400 / 19.367 .570} \\
=0,83\end{array}$ & $\begin{array}{l}\frac{97.090,46 / 6.495 .462,11}{374.180 / 20.775 .800} \\
=0,83\end{array}$ & $\begin{array}{l}\frac{101.855,69 / 6.905 .553,63}{392.590 / 22.068 .590} \\
=0,83\end{array}$ & $\begin{array}{l}\frac{105.471,51 / 7.362 .609,08}{406.470 / 23.507 .150} \\
=0,83\end{array}$ \\
\hline
\end{tabular}

Sektor Jasa Lainnya, merupakan sektor non basis karena hasil perhitungan LQ dalam periode 5 (lima) tahun menunjukkan kurang dari 1.

Dari hasil perhitungan LQ selama periode analisis (tahun 2012-2016), Sektor Pertambangan dan Penggalian, Sektor Industri Pengolahan; Sektor Pengadaan Listrik dan Gas, Sektor Kontruksi, Sektor Transportasi dan Pergudangan Sektor Informasi dan Komunikasi dan Sektor Jasa Keuangan dan Asuransi menjadi basis sektor di Kabupaten Gorontao karena berpotensi menjadi 
kegiatan basis. Berdasarkan data PDRB Kabupaten Gorontalo dan Produk Domestik Bruto (PDRB) Provinsi Gorontalo Atas Dasar Harga Konstan 2010 Tahun 2012-2016, dapat dilakukan perhitungan menggunakan metode Location Quotient (LQ) untuk mendapatkan keunggulan komparatif yang dimiliki kabupaten dibandingkan dengan perekonomian provinsi. Dengan cara yang sama terhadap perekonomian Provinsi Gorontalo, akan diketahui sektor atau kegiatan basis maupun non basis.

Pada sektor Pengadaan Listrik dan Gas, Sub sektor listrik meliputi pembangkitan tenaga listrik dan pengoperasian jaringan distribusi guna penyaluran listrik, untuk dijual kepada konsumen, baik oleh PLN maupun bukan PLN serta sub sektor pengadaan gas yang peruntukkannya segmen rumah tangga, Komersial dan Industri memiliki kontribusi yang cukup besar. Berikut informasi mengenai hasil penghitungan nilai LQ sektor listrik dan gas di Kabupaten Gorontalo pada tahun 2012-2016:

- Pada tahun 2012 sektor pengadaan listrik dan gas, memiliki nilai LQ 1,57 > 1 dengan jumlah PDRB sebesar $\mathbf{6 . 0 5 6 , 7 0}$ dalam juta rupiah selama satu tahun.

- Pada tahun 2013 sektor pengadaan listrik dan gas memiliki nilai LQ 1,57 > 1 dengan jumlah PDRB sebesar $\mathbf{6 . 4 6 3 , 4 4}$ dalam juta rupiah selama satu tahun. Dalam sektor listrik, dan gas berperan dalam peningkatan PDRB Kabupaten Gorontalo. Pada tahun 2013, nilai LQ tidak mengalami perubahan yang signifikan dari tahun 2012 ke tahun 2013. Namun jumlah PDRB tetap mengalami peningkatan. Tidak adanya perubahan signifikan untuk nilai LQ karena hal ini terjadi ketika laju pertumbuhan ekonomi sektor Provinsi Gorontalo lebih besar dari sektor Kabupaten Gorontalo.

- Pada tahun 2014 sektor pengadaan listrik dan gas memiliki nilai LQ 1,57 > 1 dengan jumlah PDRB sebesar 7.260,80 dalam juta rupiah selama satu tahun. Dalam sektor listrik, dan gas berperan dalam peningkatan PDRB Kabupaten Gorontalo ini terlihat PDRB pada tahun 2014, nilai LQ tidak mengalami perubahan yang signifikan dari tahun 2013-2014. Namun jumlah PDRB tetap mengalami peningkatan dengan bukti PDRB Kabupaten Gorontalo sektor pengadaan listrik dan gas tahun 2013 - 2014 yaitu sebesar 6.463,44 naik menjadi 7.260,80 dalam juta rupiah. Tidak adanya perubahan signifikan untuk nilai LQ karena hal ini terjadi ketika laju pertumbuhan ekonomi sektor Provinsi Gorontalo lebih besar dari sektor Kabupaten Gorontalo.

- Pada tahun 2015 sektor pengadaan listrik dan gas memiliki nilai LQ 1,57 > 1 dengan jumlah PDRB sebesar 7.348,44 dalam juta rupiah selama satu tahun. Dalam sektor listrik, dan gas berperan dalam peningkatan PDRB Kabupaten Gorontalo ini terlihat PDRB pada tahun 2015, nilai LQ tidak mengalami perubahan yang signifikan dari tahun 2014-2015. Namun jumlah PDRB tetap mengalami peningkatan dengan bukti PDRB Kabupaten Gorontalo sektor pengadaan listrik dan gas tahun 2014 - 2015 yaitu sebesar 7.260,80 naik menjadi 7.348,44 dalam juta rupiah. Tidak adanya perubahan signifikan untuk nilai LQ karena hal ini terjadi ketika laju pertumbuhan ekonomi sektor Provinsi Gorontalo lebih besar dari sektor Kabupaten Gorontalo.

- Pada tahun 2016 sektor pengadaan listrik dan gas memiliki nilai LQ 1,57 > 1 dengan jumlah PDRB sebesar 8.163,33 dalam juta rupiah selama satu tahun. Dalam sektor listrik, dan gas berperan dalam peningkatan PDRB Kabupaten Gorontalo ini terlihat PDRB. Pada tahun 2016, nilai LQ tidak mengalami perubahan yang signifikan dari tahun 2015-2016. Namun jumlah PDRB tetap mengalami peningkatan dengan bukti PDRB Kabupaten Gorontalo sektor pengadaan listrik dan gas tahun 2015 - 2016 yaitu sebesar 7.348,44 naik menjadi 8.163,33 dalam juta rupiah. Tidak adanya perubahan signifikan untuk nilai LQ karena hal ini terjadi ketika laju pertumbuhan ekonomi sektor Provinsi Gorontalo lebih besar dari sektor Kabupaten Gorontalo. 
Pada sektor Pertambangan dan Penggalian, Sub sektor pertambangan dan sub sektor penggalian. Berikut informasi mengenai hasil penghitungan nilai LQ sektor pertambangan dan penggalian di Kabupaten Gorontalo pada tahun 2012-2016:

- Pada tahun 2012 sektor pertambangan dan penggalian, memiliki nilai LQ 1,46 $>1$ dengan jumlah PDRB sebesar 120.769,80 dalam juta rupiah selama satu tahun.

- Pada tahun 2013 sektor pertambangan dan penggalian memiliki nilai LQ 1,50 $>1$ dengan jumlah PDRB sebesar 127.261,59 dalam juta rupiah selama satu tahun. Dalam sektor pertambangan dan penggalian berperan dalam peningkatan PDRB Kabupaten Gorontalo. Pada tahun 2013, nilai LQ mengalami kenaikan sebesar 0,04 dari tahun 2012 ke tahun 2013. Hal ini sinkron dengan terjadinya peningkatan jumlah PDRB. Hal ini dibuktikan besaran angka PDRB tahun 2012 hanya $\mathbf{1 2 0 . 7 6 9 , 8 0}$ pada tahun 2013 berubah menjadi 127.261,59

- Pada tahun 2014 sektor pertambangan dan penggalian memiliki nilai LQ 1,45 > 1 dengan jumlah PDRB sebesar 133.315,90 dalam juta rupiah selama satu tahun. Dalam sektor pertambangan dan penggalian berperan dalam peningkatan PDRB Kabupaten Gorontalo ini terlihat PDRB pada tahun 2014, nilai LQ mengalami penurunan antara perbandingan tahun 2013-2014 sebesar 0,05. Namun tidak mempengaruhi jumlah PDRB yang tetap mengalami peningkatan dengan bukti PDRB Kabupaten Gorontalo sektor pertambangan dan penggalian tahun 2013 - 2014 yaitu sebesar 127.261,59 naik menjadi 133.315,90 dalam juta rupiah.

- Pada tahun 2015 sektor pertambangan dan penggalian memiliki nilai LQ 1,53 $>1$ dengan jumlah PDRB sebesar 141.209,58 dalam juta rupiah selama satu tahun. Dalam sektor pertambangan dan penggalian berperan dalam peningkatan PDRB Kabupaten Gorontalo ini terlihat PDRB Pada tahun 2015, nilai LQ kembali mengalami kenaikan antara tahun 2014-2015 sebesar 0.08. Adapun jumlah PDRB tetap mengalami peningkatan dengan bukti PDRB Kabupaten Gorontalo sektor pertambangan dan penggalian tahun $2014-2015$ yaitu sebesar 133.315,90 naik menjadi 141.209,58 dalam juta rupiah.

- Pada tahun 2016 sektor pertambangan dan penggalian memiliki nilai LQ 1,54 $>1$ dengan jumlah PDRB sebesar 142.344,53 dalam juta rupiah selama satu tahun. Nilai LQ mengalami kenaikan antara perbandingan tahun 2015-2016 sebesar 0,01. Dalam sektor pertambangan dan penggalian berperan dalam peningkatan PDRB Kabupaten Gorontalo. Namun jumlah PDRB tetap mengalami peningkatan dengan bukti PDRB Kabupaten Gorontalo sektor pertambangan dan penggalian tahun 2015 - 2016 yaitu sebesar 141.209,58 naik menjadi 142.344,53 dalam juta rupiah.

Pada sektor transportasi dan pergudangan, Sub sektor transportasi dan sub sektor pergudangan. Berikut informasi mengenai hasil penghitungan nilai LQ sektor transportasi dan pergudangan di Kabupaten Gorontalo pada tahun 20122016:

- Pada tahun 2012 sektor transportasi dan pergudangan, memiliki nilai LQ $\mathbf{1 , 3 7}$ $>1$ dengan jumlah PDRB sebesar 436.020,45 dalam juta rupiah selama satu tahun.

- Pada tahun 2013 sektor transportasi dan pergudangan memiliki nilai LQ $\mathbf{1 , 3 8}$ $>1$ dengan jumlah PDRB sebesar 478.193,47 dalam juta rupiah selama satu tahun. Dalam sektor transportasi dan pergudangan berperan dalam peningkatan PDRB Kabupaten Gorontalo. Pada tahun 2013, nilai LQ mengalami kenaikan sebesar 0,01 dari tahun 2012 ke tahun 2013. Hal ini sinkron dengan terjadinya peningkatan jumlah PDRB. Hal ini dibuktikan besaran angka PDRB tahun 2012 hanya 436.020,45 pada tahun 2013 berubah menjadi $\mathbf{4 7 8 . 1 9 3 , 4 7}$ dalam juta rupiah. 
- Pada tahun 2014 sektor transportasi dan pergudangan memiliki nilai LQ 1,38 $>1$ dengan jumlah PDRB sebesar 518.829,35 dalam juta rupiah selama satu tahun. Dalam sektor transportasi dan pergudangan berperan dalam peningkatan PDRB Kabupaten Gorontalo ini terlihat PDRB pada tahun 2014, nilai LQ tidak mengalami perubahan antara tahun 2013-2014. Namun jumlah PDRB yang mengalami peningkatan dengan bukti PDRB Kabupaten Gorontalo sektor transportasi dan pergudangan tahun 2013 - 2014 yaitu sebesar 478.193,47 naik menjadi 518.829,35 dalam juta rupiah.

- Pada tahun 2015 sektor transportasi dan pergudangan memiliki nilai LQ 1,38 $>1$ dengan jumlah PDRB sebesar 566.225,95 dalam juta rupiah selama satu tahun. Dalam sektor transportasi dan pergudangan berperan dalam peningkatan PDRB Kabupaten Gorontalo ini terlihat PDRB pada tahun 2015, nilai LQ tidak mengalami perubahan antara tahun 2014-2015. Namun jumlah PDRB yang tetap mengalami peningkatan dengan bukti PDRB Kabupaten Gorontalo sektor transportasi dan pergudangan tahun 2014 - 2015 yaitu sebesar 518.829,35 naik menjadi 566.225,95 dalam juta rupiah.

- Pada tahun 2016 sektor transportasi dan pergudangan memiliki nilai LQ $\mathbf{1 , 4 0}$ $>1$ dengan jumlah PDRB sebesar 616.512,23 dalam juta rupiah selama satu tahun. Nilai LQ mengalami kenaikan antara perbandingan tahun 2015-2016 sebesar 0,02. Dalam sektor transportasi dan pergudangan berperan dalam peningkatan PDRB Kabupaten Gorontalo. Namun jumlah PDRB tetap mengalami peningkatan dengan bukti PDRB Kabupaten Gorontalo sektor pertambangan dan penggalian tahun 2015 - 2016 yaitu sebesar 566.225,95 naik menjadi $\mathbf{6 1 6 . 5 1 2 , 2 3}$ dalam juta rupiah.

Pada sektor konstruksi, Sub sektor konstruksi. Berikut informasi mengenai hasil penghitungan nilai LQ sektor konstruksi di Kabupaten Gorontalo pada tahun 2012-2016:

- Pada tahun 2012 sektor konstruksi, memiliki nilai LQ 1,31 > 1 dengan jumlah PDRB sebesar 871.666,02 dalam juta rupiah selama satu tahun.

- Pada tahun 2013 sektor konstruksi memiliki nilai LQ 1,28 > 1 dengan jumlah PDRB sebesar 913.945,55 dalam juta rupiah selama satu tahun. Dalam sektor konstruksi berperan dalam peningkatan PDRB Kabupaten Gorontalo. Pada tahun 2013, nilai LQ mengalami penurunan sebesar 0,03 dari tahun 2012 ke tahun 2013. Namun berbeda hal dengan angka PDRB, yaitu terjadinya peningkatan jumlah PDRB. Hal ini dibuktikan besaran angka PDRB tahun 2012 hanya 871.666,02 pada tahun 2013 berubah menjadi 913.945,55 dalam juta rupiah.

- Pada tahun 2014 sektor konstruksi memiliki nilai LQ 1,28 > 1 dengan jumlah PDRB sebesar 986.133,04 dalam juta rupiah selama satu tahun. Dalam sektor konstruksi berperan dalam peningkatan PDRB Kabupaten Gorontalo ini terlihat PDRB pada tahun 2014, nilai LQ tidak mengalami perubahan antara tahun 2013-2014. Namun jumlah PDRB yang mengalami peningkatan dengan bukti PDRB Kabupaten Gorontalo sektor konstruksi tahun 2013 - 2014 yaitu sebesar 913.945,55 naik menjadi 986.133,04 dalam juta rupiah.

- Pada tahun 2015 sektor konstruksi memiliki nilai LQ 1,28 > 1 dengan jumlah PDRB sebesar 1.084.547,68 dalam juta rupiah selama satu tahun. Dalam sektor konstruksi berperan dalam peningkatan PDRB Kabupaten Gorontalo ini terlihat PDRB pada tahun 2014, nilai LQ tidak mengalami perubahan antara tahun 2014-2015. Namun jumlah PDRB yang mengalami peningkatan dengan bukti PDRB Kabupaten Gorontalo sektor konstruksi tahun 2014 - 2015 yaitu sebesar 986.133,04 naik menjadi 1.084.547,68 dalam juta rupiah.

- Pada tahun 2016 sektor konstruksi memiliki nilai LQ 1,29 > 1 dengan jumlah PDRB sebesar 1.155.225,72 dalam juta rupiah selama satu tahun. Nilai LQ mengalami kenaikan antara perbandingan tahun 2015-2016 sebesar 0,01. 
Dalam sektor konstruksi berperan dalam peningkatan PDRB Kabupaten Gorontalo. Namun jumlah PDRB tetap mengalami peningkatan dengan bukti PDRB Kabupaten Gorontalo sektor konstruksi tahun 2015 - 2016 yaitu sebesar 1.084.547,68 naik menjadi 1.155.225,72 dalam juta rupiah.

Pada sektor jasa keuangan, Sub sektor jasa keuangan. Berikut informasi mengenai hasil penghitungan nilai LQ sektor jasa keuangan di Kabupaten Gorontalo pada tahun 2012-2016:

- Pada tahun 2012 sektor jasa keuangan, memiliki nilai LQ 1,06 > 1 dengan jumlah PDRB sebesar 223.669,63 dalam juta rupiah selama satu tahun.

- Pada tahun 2013 sektor jasa keuangan memiliki nilai LQ 1,10 > 1 dengan jumlah PDRB sebesar 231.911,62 dalam juta rupiah selama satu tahun. Dalam sektor jasa keuangan berperan dalam peningkatan PDRB Kabupaten Gorontalo. Pada tahun 2013, nilai LQ mengalami kenaikan sebesar 0,04 dari tahun 2012 ke tahun 2013. Dan hal ini dibuktikan dengan angka PDRB, yaitu terjadinya peningkatan jumlah PDRB, yaitu tahun 2012 hanya 223.669,63 pada tahun 2013 berubah menjadi 231.911,62 dalam juta rupiah.

- Pada tahun 2014 sektor jasa keuangan memiliki nilai LQ 1,09 > 1 dengan jumlah PDRB sebesar 242.398,28 dalam juta rupiah selama satu tahun. Dalam sektor jasa keuangan berperan dalam peningkatan PDRB Kabupaten Gorontalo ini terlihat PDRB pada tahun 2014, nilai LQ mengalami penurunan sebesar 0,01 dibandingkan dengan tahun sebelumnya. Namun jumlah PDRB yang mengalami peningkatan dengan bukti PDRB Kabupaten Gorontalo sektor jasa keuangan tahun 2013 - 2014 yaitu sebesar 223.669,63 naik menjadi 242.398,28 dalam juta rupiah.

- Pada tahun 2015 sektor jasa keuangan memiliki nilai LQ 1,16 > 1 dengan jumlah PDRB sebesar 268.868,83 dalam juta rupiah selama satu tahun. Dalam sektor jasa keuangan berperan dalam peningkatan PDRB Kabupaten Gorontalo ini terlihat PDRB pada tahun 2014, nilai LQ mengalami perubahan antara tahun 2014-2015 sebesar 0,07. Dan jumlah PDRB yang mengalami peningkatan dengan bukti PDRB Kabupaten Gorontalo sektor jasa keuangan tahun 2014 - 2015 yaitu sebesar $\mathbf{2 4 2 . 3 9 8 , 2 8}$ naik menjadi $\mathbf{2 6 8 . 8 6 8 , 8 3}$ dalam juta rupiah.

- Pada tahun 2016 sektor jasa keuangan memiliki nilai LQ 1,25 > 1 dengan jumlah PDRB sebesar 319.793,01 dalam juta rupiah selama satu tahun. Nilai LQ mengalami kenaikan antara perbandingan tahun 2015-2016 sebesar 0,09. Dalam sektor konstruksi berperan dalam peningkatan PDRB Kabupaten Gorontalo. Namun jumlah PDRB tetap mengalami peningkatan dengan bukti PDRB Kabupaten Gorontalo sektor jasa keuangan tahun 2015 - 2016 yaitu sebesar 268.868,83 naik menjadi 319.793,01 dalam juta rupiah.

Pada sektor informasi dan komunikasi, Sub sektor informasi dan sub sektor komunikasi. Berikut informasi mengenai hasil penghitungan nilai LQ sektor informasi dan komunikasi di Kabupaten Gorontalo pada tahun 2012-2016:

- Pada tahun 2012 sektor informasi dan komunikasi, memiliki nilai LQ 1,08 > 1 dengan jumlah PDRB sebesar 166.849,14 dalam juta rupiah selama satu tahun.

- Pada tahun 2013 sektor informasi dan komunikasi memiliki nilai LQ 1,07 > 1 dengan jumlah PDRB sebesar 180.313,72 dalam juta rupiah selama satu tahun. Dalam sektor informasi dan komunikasi berperan dalam peningkatan PDRB Kabupaten Gorontalo. Pada tahun 2013, nilai LQ mengalami penurunan sebesar 0,01 dari tahun 2012 ke tahun 2013. Namun berbeda dengan angka PDRB, yaitu terjadinya peningkatan jumlah PDRB, yaitu tahun 2012 hanya $\mathbf{1 6 6 . 8 4 9 , 1 4}$ pada tahun 2013 berubah menjadi $\mathbf{1 8 0 . 3 1 3 , 7 2}$ dalam juta rupiah. 
- Pada tahun 2014 sektor informasi dan komunikasi memiliki nilai LQ 1,06 > 1 dengan jumlah PDRB sebesar 194.999,50 dalam juta rupiah selama satu tahun. Dalam sektor informasi dan komunikasi berperan dalam peningkatan PDRB Kabupaten Gorontalo ini terlihat PDRB pada tahun 2014, nilai LQ mengalami penurunan sebesar 0,01 dibandingkan dengan tahun sebelumnya. Namun jumlah PDRB tetap mengalami peningkatan dengan bukti PDRB Kabupaten Gorontalo sektor informasi dan komunikasi tahun 2013 - 2014 yaitu sebesar 180.313,72 naik menjadi 194.999,50 dalam juta rupiah.

- Pada tahun 2015 sektor Informasi dan komunikasi memiliki nilai LQ 1,06 > 1 dengan jumlah PDRB sebesar 214.157,73 dalam juta rupiah selama satu tahun. Dalam sektor Informasi dan komunikasi berperan dalam peningkatan PDRB Kabupaten Gorontalo ini terlihat PDRB. Nilai LQ tidak mengalami perubahan antara tahun 2014-2015. Dan jumlah PDRB yang mengalami peningkatan dengan bukti PDRB Kabupaten Gorontalo sektor informasi dan komunikasi tahun 2014 - 2015 yaitu sebesar $\mathbf{1 9 4 . 9 9 9 , 5 0}$ naik menjadi 214.157,73 dalam juta rupiah.

- Pada tahun 2016 sektor informasi dan komunikasi memiliki nilai LQ 1,04 > 1 dengan jumlah PDRB sebesar 231.483,10 dalam juta rupiah selama satu tahun. Nilai LQ kembali mengalami penurunan sebesar 0,02 dibandingkan dengan tahun sebelumnya. Dalam sektor informasi dan komunikasi berperan dalam peningkatan PDRB Kabupaten Gorontalo. Jumlah PDRB tetap mengalami peningkatan dengan bukti PDRB Kabupaten Gorontalo sektor informasi dan komunikasi tahun 2015 - 2016 yaitu sebesar 214.157,73 naik menjadi 231.483,10 dalam juta rupiah.

Pada sektor industri pengolahan, juga memiliki kontribusi yang cukup besar dalam meningkatkan nilai PDRB Kabupaten Gorontalo dengan beberapa sub sektor yang mendukung sektor industri pengolahan. Berikut informasi mengenai hasil penghitungan nilai LQ sektor industri pengolahan di Kabupaten Gorontalo pada tahun 2012-2016 :

- Pada tahun 2012 sektor industri pengolahan, memiliki nilai LQ 1,03 > 1 dengan jumlah PDRB sebesar 235.569,73 dalam juta rupiah selama satu tahun.

- Pada tahun 2013 sektor industri pengolahan memiliki nilai LQ 1,05 > 1 dengan jumlah PDRB sebesar 259.474,78 dalam juta rupiah selama satu tahun. Dalam sektor industri pengolahan berperan dalam peningkatan PDRB Kabupaten Gorontalo. Pada tahun 2013, nilai LQ mengalami kenaikan sebesar 0,02 dari tahun 2012 ke tahun 2013. Namun berbeda dengan angka PDRB, yaitu terjadinya peningkatan jumlah PDRB, yaitu tahun 2012 hanya 235.569,73 pada tahun 2013 berubah menjadi $\mathbf{2 5 9 . 4 7 4 , 7 8}$ dalam juta rupiah.

- Pada tahun 2014 sektor industri pengolahan memiliki nilai LQ 1,04>1 dengan jumlah PDRB sebesar 194.999,50 dalam juta rupiah selama satu tahun. Dalam sektor informasi dan komunikasi berperan dalam peningkatan PDRB Kabupaten Gorontalo ini terlihat PDRB pada tahun 2014, nilai LQ mengalami penurunan sebesar 0,01 dibandingkan dengan tahun sebelumnya. Namun jumlah PDRB tetap mengalami peningkatan dengan bukti PDRB Kabupaten Gorontalo sektor informasi dan komunikasi tahun 2013 - 2014 yaitu sebesar 180.313,72 naik menjadi 194.999,50 dalam juta rupiah.

- Pada tahun 2015 sektor Informasi dan komunikasi memiliki nilai LQ 1,06 > 1 dengan jumlah PDRB sebesar 214.157,73 dalam juta rupiah selama satu tahun. Dalam sektor Informasi dan komunikasi berperan dalam peningkatan PDRB Kabupaten Gorontalo ini terlihat PDRB. Nilai LQ tidak mengalami perubahan antara tahun 2014-2015. Dan jumlah PDRB yang mengalami peningkatan dengan bukti PDRB Kabupaten Gorontalo sektor informasi dan 
komunikasi tahun 2014 - 2015 yaitu sebesar $\mathbf{1 9 4 . 9 9 9 , 5 0}$ naik menjadi 214.157,73 dalam juta rupiah.

- Pada tahun 2016 sektor informasi dan komunikasi memiliki nilai LQ 1,04 > 1 dengan jumlah PDRB sebesar 231.483,10 dalam juta rupiah selama satu tahun. Nilai LQ kembali mengalami penurunan sebesar 0,02 dibandingkan dengan tahun sebelumnya. Dalam sektor informasi dan komunikasi berperan dalam peningkatan PDRB Kabupaten Gorontalo. Jumlah PDRB tetap mengalami peningkatan dengan bukti PDRB Kabupaten Gorontalo sektor informasi dan komunikasi tahun 2015 - 2016 yaitu sebesar 214.157,73 naik menjadi 231.483,10 dalam juta rupiah.

Berdasarkan hasil analisis keseluruhan terhadap ke-tujuh sektor yang dianggap menjadi basis Kabupaten Gorontalo dari tahun 2012 hingga 2016, sektor Konstruksi dan sektor Informasi dan Komunikasi mengalami penurunan nilai LQ pada tahun 2013. Sektor Pertambangan dan Penggalian mengalami penurunan nilai LQ sebesar 0,05 di tahun 2014. Namun kembali mengalami peningkatan pada periode analisis selanjutnya yaitu di tahun 2014-2016. Hal yang sama terjadi di sektor Industri Pengolahan Kemudian terjadinya peningkatan di periode tahun 2012-2013, tetapi tahun berikutnya terjadi penurunan angka LQ. Untuk sektor Jasa Keuangan terjadi peningkatan dari tahun ke tahun, walaupun di periode tahun 2013-2014 mengalami penurunan angka LQ sebesar 0,01 dan tahun berikutnya mengalami kenaikan LQ hingga tahun 2016. Sedangkan sektor transportasi dari tahun ke tahun nilai LQ mengalami kenaikan dari tahun 2012 2016. Serta sektor Pengadaan Listrik dan Gas tidak mengalami perubahan, artinya nilai LQ statis dari periode 2012-2016.

Peningkatan ataupun penurunan nilai LQ ini disebabkan laju pertumbuhan ekonomi Kabupaten Gorontalo sedang lebih besar atau lebih kecil dibandingkan dengan Provinsi Gorontalo. Pada sektor Pertambangan dan Penggalian dan sektor Transportasi dan Pergudangan, nilai LQ dengan jumlah PDRB senantiasa mengalami peningkatan secara stabil. Oleh karena itu, dari ke-tujuh sektor basis Kabupaten Gorontalo, sektor Pengadaan Listrik dan Gas merupakan sektor yang paling stabil untuk dijadikan kegiatan basis di wilayah Kabupaten Gorontalo. Dengan kontribusi yang cukup tinggi dan juga nilai LQ Kabupaten Gorontalo terhadap perekonomian Provinsi Gorontalo yang juga cukup tinggi menjadikan kegiatan ini sebagai kegiatan basis yang sangat baik untuk dikembangkan karena banyak sekali dampak positif yang ditimbulkan dari sektor ini. Pada sektor sektor Pengadaan Listrik dan Gas, memberikan peran yang sangat besar terhadap kebutuhan masyarakat Kabupaten Gorontalo baik untuk skala industri ataupun kebutuhan perkantoran sampai dengan konsumsi rumah tangga. Sekalipun gebrakan kenaikan TDL (tarif dasar listrik) mengalami kenaikan, namun kebutuhan akan energi tetap meningkat.

Upah Minimum Regional (UMR) Kabupaten Gorontalo cukup tinggi apabila dibandingakn dengan kabupaten terdekatnya. Karena majunya pertumbuhan ekonomi Kabupaten Gorontalo banyak pengusaha yang menginvestasikan modalnya diberbagai sektor basis di Kabupaten Gorontalo untuk membangun kontruksi, membangun jasa keuangan, atau mendirikan industri, dan secara tidak langsung meningkatkan Pendapatan Daerah. Dengan berkembangnya sektor ini memungkinkan sektor lain yang menyediakan bahan baku bisa ikut tumbuh berkembang, terlebih lagi bila industri tersebut menggunakan bahan baku lokal. Pada sektor jasa keuangan, peningkatan LQ didukung oleh banyaknya instansi pemerintahan yang didirikan di Kabupaten Gorontalo, sesuai Undang-undang Nomor 29 Tahun 1959 pada Bulan Juli 1959 bahwa Kecamatan Limboto menjadi ibukota Kabupaten Gorontalo, sehingga sarana prasarana pemerintahan mulai lebih dilengkapi. Sarana prasarana yang sudah lengkap dan bagus, akan 
mendatangkan daya tarik masyarakat untuk memanfaatkannya sehingga nilai LQ untuk jasa-jasa terus mengalami peningkatan.

\section{KESIMPULAN}

Dari ke-tujuh sektor basis Kabupaten Gorontalo, sektor Pengadaan Listrik dan Gas merupakan sektor yang paling stabil untuk dijadikan kegiatan basis di wilayah Kabupaten Gorontalo. Dengan kontribusi yang cukup tinggi dan juga nilai LQ Kabupaten Gorontalo terhadap perekonomian Provinsi Gorontalo yang juga cukup tinggi menjadikan kegiatan ini sebagai kegiatan basis yang sangat baik untuk dikembangkan karena banyak sekali dampak positif yang ditimbulkan dari sektor ini.

\section{REFERENSI}

Arsyad, Lincolin. (1999). Pengantar Perencana dan pembangunan Ekonomi Daerah. BPFE Yogyakarta

BPS Kabupaten Gorontalo. PDRB Kabupaten Gorontalo menurut Lapangan Usaha atas Dasar Harga Konstan 2000 Tahun 2012-2016 (dalam juta rupiah), (online) https://gorontalokab.go.id, (diakses pada tanggal 6 November 2017)

BPS Provinsi Gorontalo. PDRB Provinsi Gorontalo menurut Lapangan Usaha atas Dasar Harga Konstan 2000 Tahun 2012-2016 (dalam milyar rupiah), (online) https://gorontaloprov.go.id, (diakses pada tanggal 10 November 2017)

Kartikaningdyah, Ely. Analisis Location Quotient Dalam Penentuan Produk Unggulan Pada Beberapa Sektor di Kabupaten Lingga Kepulauan Riau Batam.

Kohar, Abdul dan Agus Suherman. Analisis Location Quotient (LQ) dalam Penentuan Komoditas Ikan Unggulan Perikanan tangkap Kabupaten Cilacap

Hendayana, R. 2003. Aplikasi Metode Location Qoutient (LQ) Dalam Penentuat Komoditas Unggunal Nasional. Jurnal Informatika Pertanian Volume 12. Balai Besar Pengkajian dan Pengembangan Teknologi Pertanian Bogor. http://www.litbangdeptan.go.id (diakses tanggal 9 November 2017) 